\title{
La biopolítica em las aulas: prácticas de conducción em las escuelas elementares del Reino de Baviera, Alemanha (1869-1919).
}

\section{Luciano Mendes de Faria Filho ${ }^{1}$}

CARUSO, Marcelo. La biopolítica em las aulas: prácticas de conducción em las escuelas elementares del Reino de Baviera, Alemanha (1869-1919). Buenos Aires: Prometeo Libros, 2005. 471p.

Nos textos publicados sobre a história da educação, em várias partes do mundo, tem sido lugar-comum afirmar sobre o vigor das pesquisas neste campo, as quais não cessam de crescer e conquistar prestígio acadêmico. Fala-se, também, na riqueza analítica e temática dos trabalhos, realçando-se, ainda, a crescente qualidade das investigações apresentadas nos congressos e publicadas em livros e revistas da área. Se, por um lado, muitas vezes somos levados a considerar, com certa suspeição, este diagnóstico demasiadamente positivo, por outro, trabalhos como o do professor Marcelo Caruso, que ora comento, acabam por justificar esse otimismo em relação à área.

O livro resulta da publicação da tese de doutoramento defendida na Universidade Ludwig-Maximilian (Munique, Alemanha) e apresenta uma refinada análise, baseada na obra de Michel Foucault, sobre a escola primária da Baviera. Fundamentalmente, o trabalho "intenta mostrar que

\footnotetext{
1 Doutor em Educação. Professor da Faculdade de Educação da UFMG.
} 
a cotidianeidade, em sua gramática, em sua variabilidade e em seus paradoxos, também pode ser entendida desde a teoria da governamentabilidade, sem, no entanto, que esta seja entendida como uma chave todos e cada um dos processos em jogo" (p. 12).

Se, por um lado, o trabalho desenvolvido por Marcelo Caruso tem forte vetor teórico-metológico, por outro, é marcado também pela preocupação com a escola latino-americana, da qual ele é, também, um estudioso. Assim, as políticas educativas desenvolvidas na América Latina nas últimas décadas, particularmente na Argentina, seu país natal, somadas às preocupações com o fazer cotidiano da escola primária são dimensões do tempo que ajudam o pesquisador na elaboração de interrogações sobre o passado educacional do mundo ocidental. Assim, no trabalho sobre a Baviera, não cessamos de encontrar ressonâncias da escola argentina, mas também da brasileira, da francesa, da inglesa e de diversas outras partes do mundo.

Essas já seriam razões para tornar a leitura do livro necessária para todos aqueles que se preocupam com a história da escola e, mais do que isso, com a sorte desta instituição no mundo contemporâneo. Mas o livro nos oferece mais. Do ponto de vista teórico, há o refinamento da teoria focaultiana à medida que é convidada a dialogar com ricos dados empíricos, embora, segundo afirma Caruso, não se considere que Foucault vá resolver todos os problemas postos pela investigação. Esse refinamento é visível tanto na recusa de uma aplicação mecânica das categorias cunhadas pelo autor francês, quanto na distinção elaborado por Marcelo entre a disciplina "mecânica", observada até o início do século, e a regulação (biopolítica) que terá lugar nas sociedades contemporâneas a partir de então. Por isso, segundo Caruso, "é preciso sublinhar que a 'regulação', como forma específica de intervenção biopolítica, recebeu, no período de sua forja, um significado particular. No alvorecer do século XIX, pode-se verificar uma resignificação do tono orgânico e organicista 
no campo semântico dos conceitos de regulação" (p. 53). A partir dessa premissa, amplamente discutida e demonstrada ao longo do trabalho, Marcelo Caruso define regulação como "um conjunto de ações operativas e de processos de simbolização em um padrão de 'boa' ordem de caráter orgânico e cujo objetivo é fomentar e dirigir, ao mesmo tempo, os processos de crescimento" (p. 59).

O trabalho de Marcelo é um bom exemplo de maestria na pesquisa, já que permite visualizar um pesquisador que não se deixa escravizar pelas tiranias da teoria que abraça, buscando dar-lhe emprego refinado e criativo. Desse modo, a tão decantada criatividade do pesquisador não é substituta da erudição; pelo contrário, a erudição criativa é demonstrada não apenas na refinada revisão teórica presente no livro, mas também, e sobretudo, na forma como o autor dialoga com os pares de várias partes do mundo.

Um dos aspectos mais interessantes do livro é, justamente, a capacidade demonstrada por Marcelo Caruso de trazer os aportes de diversas ciências para o entendimento de questões pertinentes ao campo educacional, fazendo-nos ver a relevância de outras teorias para a compreensão da vida social na Baviera de finais do século XIX e início do XX. Assim é que a discussão que ele faz sobre a sala de aula, sua organização e seu cotidiano, ao mesmo tempo que permite certa aproximação com uma escola que se institucionalizava, remete também para as grandes questões políticas postas para uma sociedade em crescente mutação. A sala de aula articulava-se, assim, à constituição do Estado e às lutas políticas mais amplas.

Desse modo, o livro apresenta uma importante contribuição à história da escola no mundo ocidental. Ao mesmo tempo que desnaturaliza a escola, mostrando a sua historicidade, Marcelo o faz alargando nossos horizontes para aquelas dimensões da vida social, coletiva e individual que são continuamente tensionadas pela crescente 
importância atribuída a essa instituição na socialização das novas gerações. Assim, escrever a história da escolarização é, em boa parte, escrever a história da Baviera em um de seus momentos de realização.

O olhar atento do estudioso volta-se, como já se disse, para a escola em sua configuração simbólica e material. A crescente importância da escola como "técnica de governo" que põe em marcha uma regulação biopolítica é dissecada quando o autor articula regulação pedagógica, ensino e modernidade. Da mesma forma, a materialidade da escola comparece no estudo como uma das dimensões fundamentais de produção de uma tecnologia ou de um conjunto de imperativos especificamente escolares.

O autor volta sua atenção também para as crianças. Sobretudo ao analisar o textos de Kerschensteiner, ele mostra como uma importante mutação na compreensão da criança estava se processando naquele momento. Defende que a noção de criança como sujeito em crescimento cria as condições para a rearticulação do conjunto das práticas pedagógicas escolares. O conceito de trabalho, por exemplo, tão fundamental naquele momento no pensamento pedagógico, deveria passar a significar uma atividade vinculada ao crescimento físico e mental da criança. Por essa via, tornava-se obrigatória para a escola a compreensão e a incorporação dos interesses das crianças numa prática pedagógica renovada.

Como se pode notar, o livro trata de um conjunto de aspectos de grande relevância para o entendimento da história da institucionalização e da expansão da escola no mundo ocidental. Integram, ainda, tal preocupação, além das dimensões comentadas, outras relacionadas tanto ao cotidiano da escola quanto aos conteúdos e métodos de ensino. $\mathrm{O}$ estudo articula elementos específicos da história da escola e da escolarização na Baviera - tais como a relação entre a adoção da obrigatoriedade, em meados do século XIX, sem que esta estivesse 
articulada à gratuidade, só garantida no século XIX - como dimensões universalizantes do fenômeno que estuda.

Por todas essas razões, o livro de Marcelo Caruso é leitura necessária e enriquecedora para aqueles que se interessam não apenas pelo estudo de nosso passado educacional, mas para os que estão atentos também à sorte da escola nos dias de hoje. De várias formas, a obra diz: aquela escola inventada lá percorreu o século XX e nos interpela hoje. Seremos nós capazes de reinventá-la?

Recebimento: 26/08/2007

Aprovação: 05/10/2007

\section{Contato:}

Rua Francisco Proença 195/202

Bairro Santa Rosa

Belo Horizonte

CEP: $31255-800$

E-mail: mail:lucianom@ufmg.br 